Educational Research for Social Change (ERSC)

Volume: 6 No. 2, September 2017

pp. 115-132

ersc.nmmu.ac.za

ISSN: 2221-4070

\title{
An Autoethnographic Exploration of Disability Discourses: Transforming Science Education and Research for Students with Learning Disabilities
}

\author{
Neerusha Baurhoo \\ Department of Integrated Studies in Education, McGill University, PhD Candidate in Educational \\ Studies \\ neerusha.baurhoo@mail.mcaill.ca
}

\section{Abstract}

In this autoethnographic inquiry, I examine the dominant disability discourses that inform practice and research in science education for individuals with disabilities. Guided by my experience as a practitioner-researcher, I use reflexive vignettes and photo elicitation to discuss and critique disability discourses (e.g., the medical and social models of disability) that construct students with learning disabilities (LD) as disadvantaged learners. For example, the medical model of disability pathologises students with LD by focusing on their individual deficits and blaming them for their academic struggles and failures in science. In contrast, the social model of disability locates the problem solely within the students' environment (e.g., teaching strategies) and does not consider within-individual issues (e.g., cognitive deficits). By navigating through these discourses, I found my voice as a practitioner-researcher in Bronfenbrenner's (2005) ecological model, which recognises that individuals' barriers stem from their characteristics as well as their complex, multilayered environment. This article, embedded within a reflexive process, illuminates my journey of self-transformation as a practitioner-researcher while transforming and bringing educational changes to the academic lives of my students with LD.

Keywords: transformative doctoral journey, medical model of disability, social model of disability, Bronfenbrenner's ecological framework, science education, learning disabilities

Copyright: (C) 2017 Baurhoo

This is an open access article distributed under the terms of the Creative Commons Attribution Non-Commercial License, which permits unrestricted non-commercial use, distribution, and reproduction in any medium, provided the original author and source are credited.

Please reference as:

MBaurhoo, N. (2017). An Autoethnographic Exploration of Disability Dscourses: Transforming Science Education and Research for Students with Learning Disabilities. Educational Research for Social Change, 5(2), 115-132. http://dx.doi.org/10.17159/2221-4070/2017/v6i2a8 


\section{Introduction}

I cannot drop the feeling that this matters. It seems so important, what we are doing here for these people: to give them what they need most, to provide them what is most indispensable for their bare survival. This is what makes a difference in people's lives, and isn't that what it is all about: to make a difference? (Hemelsoet, 2014, p. 220)

In 2009, I began to work as a science and math special needs educator in the Office for Students with Disabilities at a college in Montreal, Quebec. My tasks involved assessing the psychoeducational reports of students with special needs to provide them with the necessary accommodations (e.g., notetaker) to support their learning. I was also responsible for designing and conducting individualised remedial tutorials for students with learning disabilities (LD) to favour their success in science and math.

As the semesters went by, I found that the majority of students with LD were struggling or failing in science. Science teachers shared with me their internal struggles to understand and academically support students with LD. Each semester, students with LD were dropping out of the science programmes and embracing other fields of study (e.g., computer science). The disappointment and sadness were evident in their voices as they told me that science was no longer for them. As a biologist (with a master's degree in animal science), I could fathom their sentiments of having their beloved science snatched away from them. Their dreams of becoming medical doctors, veterinarians, or engineers were crumbling.

I felt that these students deserved to be understood and supported to pursue their studies in science. I was determined to make a difference in their academic lives. As such, I kept asking: "What academic struggles do students with LD face in learning college science? How can we ${ }^{3}$ support these students in overcoming their struggles and enjoying success in science?" I began exploring the literature on students with disabilities in science education to comprehend their academic barriers. To my disappointment, studies researching barriers faced by students with LD were very sparse in the science and special education literature. In fact, the term learning disability is rarely found in science education literature, as pointed out by Brigham, Scruggs, and Mastropieri (2011). These authors discussed that the Handbook of Research on Science Education by Abell and Lederman (2007), which is the "holy grail" in science education, "omits the term learning disability from the index describing over 1,300 pages of text devoted to science education" (as cited in Brigham et al., 2011, p. 224).

Disappointed with the lack of research on students with LD in science, I embarked on my doctoral journey in 2011, determined to listen to voices of students with LD on obstacles that impede their learning in science. Being a critical and interpretivist researcher, I could not ignore that "a researcher's own individual mindset, bias, skills, and knowledge become an intrinsic part of the research process" (Knight \& Cross, 2012, p. 44). As I engaged in the research process, I realised that I was also "part of the world being studied" (Knight \& Cross, 2012, p. 44) because I was interacting directly with students with LD on a daily basis to understand their difficulties and support them academically. My practical experiences-as a special needs educator and a biology teacher working with students with LD-were central and influential in adopting a particular disability discourse to inform my doctoral study. For example, embodied in my role as a special needs educator (from 2009-2014), I solely focused on the specific disability types that these students displayed when I provided them with the necessary accommodations. As such, I found myself positioned within the medical model of disability, which views learning disability as a brain-based pathology. This model attributes the academic failure of

\footnotetext{
${ }^{3}$ I am referring to teachers, administrators, and special needs educators.
} 
students with LD solely to their disability, while ignoring other issues (e.g., classroom practices) that could potentially explain their academic struggles.

As I conformed to my role as a college biology teacher in 2015 , I found myself listening to voices of students with LD and transforming my classroom practices to favour their academic success. No longer did I feel that their learning disability was the sole cause of their failure. As such, I found myself aligning with the social model of disability, which attributes the academic failure of students with LD to the lack of accommodation in educational institutions (Lindsay, 2003). Yet, stemming from my practice, I also witnessed the limitations of the social model of disability. Noting the limitations of both models, I embarked on a journey to embrace a theoretical lens that offers a comprehensive and holistic understanding of the confounding issues experienced by students with LD. I found my voice in Bronfenbrenner's (2005) ecological model, which allowed me to make sense of a diversity of issues that students with LD face in learning science.

In this autoethnographic inquiry, I draw on my experiences as a practitioner-researcher to reconstruct my doctoral journey. In doing so, I explore the evolution of my research project as I navigated across diverse disability discourses, including the medical, social, and ecological models of disability. Through this tumultuous academic navigation, I have become an agent of change, transforming my teaching practice to favour an inclusive approach that focuses on diverse science learners. By adopting Bronfenbrenner's (2005) ecological model as a research lens, I am confident that I have provided ways to transform the landscape of science, special needs, and inclusive education. Specifically, I offer a new and holistic inquiry approach to exploring barriers experienced by science students with LD. I hope that this autoethnographic inquiry inspires practitioner-researchers to become agents of change and transform education for minorities such as students with LD.

\section{Embodying Autoethnography: Connecting the Practitioner to the Researcher}

Autoethnography is an "autobiographical genre of writing and research" that embeds "multiple layers of consciousness" by connecting the personal to the social, cultural, and political (Ellis, 2004, p. 37). As such, autoethnography offers a "unique window through which the external world is understood" (Stanley, 2014, p. 148). In this inquiry, I specifically focus on the analytical and evocative forms of autoethnography to reconstruct my lived experiences.

Analytical autoethnography invites me to position myself as a "complete member researcher" and "make myself visible explicitly in the text" by openly discussing my personal views and experiences regarding disability issues (Anderson, 2006; Weaver-Hightower, 2012, p. 463). In particular, I "textually acknowledge" and "reflexively assess" the ways in which I, the practitioner-researcher, have transformed my views, practices, and understanding of science students with LD in college settings (Anderson, 2006, p. 385). Analytical autoethnography also invites me to "use empirical data to gain insight into some broader set of social phenomena than those provided by the data themselves" (Anderson, 2006, p. 387). Similar to Weaver-Hightower (2012), I have drawn on interview data from science students with LD on academic barriers affecting their learning. Moreover, I have embedded arguments from the broader literature on disability discourses, special needs, and inclusive education.

As mentioned earlier, I also form part of the "world" that I am studying as I work closely with students with LD as a special needs educator and a teacher. As such, in this inquiry, I draw on evocative autoethnography to include my "sensory and emotional" experiences while reflecting on disability discourses and working with students with LD (Ellis, 2004, p. 46). I experienced grief and sadness when my students with LD shared their distress of being trapped within the medical model of disability. I also expressed joy when my students with LD overcame their difficulties and succeeded academically. I 
have used written texts, my reflection logs as a special needs educator, and my teaching dairies, to construct reflexive vignettes. Reflexive vignettes represent vivid portrayals of daily events that elicit strong and powerful emotions and understanding from the readers (Humphreys, 2005). Data in the form of photographs taken by students in my classrooms and during tutorials were used in "a process of emotional recall" that provided access to lived emotions and events that occurred at a particular point in time (Ellis, 1999, p. 675).

By using an autoethnographic lens, I reveal my vulnerable self and my intimate thoughts on the ways that disability discourses have shaped my experiences as a practitioner-researcher and, in turn, affected my students with LD in their construction of their identities as learners.

\section{The Medical Model of Disability: An Outsider's Perspective}

Learning disability is neurological, physical and cellular. Let us not forget this basic fact, for it is a truism, and it should be the rock upon which all else in this field is built. (Cruickshank, 1971, p. 73)

While there is no universal definition for learning disability, most countries collectively draw on a medical framework to explain LD. For example, the ministries of education in most Canadian provinces (e.g., British Columbia, Alberta, Nova Scotia, and Ontario, amongst others) define LD as a "neurobiologically-based medical or disease condition, which is either caused by, associated with, or results in any number of cognitive processing deficits" that affect learning and well-being of individuals (Kozey \& Siegel, 2008, p. 169). Similar to the above-mentioned provinces, the Learning Disabilities Association of Canada (2015, para. 2) employed a medical framework to define LD as "impairments in one or more processes related to perceiving, thinking, remembering, or learning. These include, but are not limited to: language processing; phonological processing; visual spatial processing; processing speed; memory and attention; and executive functions (e.g., planning and decision-making)."

This medical definition of LD stems from the basis that the brain is the site for several activities (e.g., perception, memory, emotion, and ideation), which are termed brain-based functions. As such, any deficits within those activities (e.g., memory) might affect normal brain-based functioning and lead to brain-based disorders that negatively affect individuals' lives (Anastasiou \& Kauffman, 2013). Through valid psychometric tests, students with LD can be diagnosed and areas of their cognitive difficultiesworking memory, verbal comprehension, processing, and attention-can be identified. These psychometric tests provide an understanding of ways to support the learning process of students with LD. Empirical studies have shown strong relationships between such cognitive difficulties (e.g., working memory ${ }^{4}$ ) and learning abilities (Alloway, 2009). For example, research has demonstrated that working memory capacity is positively correlated to academic scores in mathematics, and is also a strong predictor of learning outcomes in mathematics for children with LD (Alloway, 2009; Daneshamooz, Alamolhodaei, \& Darvishian, 2012).

In science education, various studies have drawn on the medical model of disability to explore difficulties that students with LD experience as compared to typically achieving peers. These studies have demonstrated that students with LD experience significant cognitive difficulties in reading science texts, retrieving prior scientific knowledge, engaging in critical thinking and reasoning during science activities, generating hypotheses, making predictions during science experiments, and applying

\footnotetext{
${ }^{4}$ Working memory is the ability to remember and use relevant information while being engaged in an activity. For example, students use their working memory as they recall steps of a math problem while simultaneously solving the math problem.
} 
constructed scientific knowledge to new contexts (Mastropieri, Scruggs, Boon, \& Carter, 2001; Scruggs \& Mastropieri, 1994).

The above-mentioned research studies, grounded in the medical model of disability, clearly demonstrate that learning difficulties faced by students with LD are primarily due to internal cognitive deficits. As such, to support these students' academic achievement and retention in education, the ministries of education in various Canadian provinces warrant that students with suspected cognitive deficits undergo diagnosis by medical experts, and be identified as having a learning disability to receive special accommodations by educational institutions (Kozey \& Siegel, 2008). For example, several accommodations are provided to students to support them in their learning, such as extra time to complete assessments, computers for writing tests, notetakers or scribes, and writing exams in a room with reduced distractions (Larochette \& Harrison, 2012).

\section{The Perils of Medicalising Disability: Oppression of Science Students With LD}

As a special needs educator, I used to feel that the medical model of disability contributed significantly to the academic success of students with LD. However, my meeting with Zeal, a first-year college student with LD, changed my perspective. As the following vignette demonstrates, being identified as having an LD and disclosing their accommodations are sources of continuous stress and tension for these students.

\section{Vignette I: Why should you send them my accommodation letter?}

Zeal, a first-year college student, met with me to set up his accommodations. Given that he experienced processing deficits, his psychologist recommended accommodations such as extra time for completing his assessments and a computer for test taking. During our meeting, Zeal explained that he experienced difficulties taking notes while teachers explained concepts. He felt that the teachers explained concepts at an extremely fast pace and that he took too much time to process and write down the information. I felt a notetaker would be helpful to fill in the gaps of missing information in Zeal's notes. As we concluded our session, he looked happy and excited that he would receive the support he needed. I assured him that I would send his accommodation letter to his teachers. After hearing that, Zeal looked upset and scared. He told me: "Why do they need to know about me? Why should you send them the accommodation letter? It will be high school all over again. They will blame me when I don't get it. They will say it's because of my disability. . . . I want to be treated like others. I want to get support without them knowing that I am registered with the OSD [Office for Students with Disabilities] and that I am abnormal." (Personal notes, special needs educator reflection log, fall semester 2012)

Like Zeal, many students whom I met during my career as a special needs educator were uncomfortable that their teachers and other people might become aware of their issues and accommodations. My experience with such issues resonates with research findings that show that attributing the LD label to students makes them feel vulnerable (Lyons \& Roulstone, 2016). Because they believe they are "not intelligent" or "smart," students with LD tend to develop lower selfconfidence and self-concept as compared to their peers without LD (Lyons \& Roulstone, 2016). To make matters worse, terms such as special needs, learning disability, and accommodations have been shown to invoke pity and sorrow from society, thus negatively affecting students' views of themselves and their abilities (Lyons \& Roulstone, 2016). 
In order to foster positive attitudes among my students with LD, I explained to them the benefits of teachers knowing about their accommodations (e.g., teachers could offer tailored, one-on-one academic support to them during office hours). Still, they insisted that not all science teachers would view them positively. They shared that their science teachers in high school discouraged them from pursuing science. Similar to my students' experiences of being oppressed, Liz Crow, an artist-activist with a physical disability, shared her heartbreaking story of having her accommodations withdrawn by the university where she was a medical student. Consequently, she failed her exams and was expelled from university:

I was kicked out of uni for being a cripple. I was up front about what I needed when I started, but half way through the year they withdrew my provision so I couldn't take my exams, and therefore, failed on a technicality. I was a medical student and if you peel back the layers, there wasn't a fit between me and the course from the university's perspectives. (Crow, 2009, para. 10)

Research has also demonstrated that science educators have negative attitudes towards students with disabilities (Norman, Caseau, \& Stefanich, 1998). For example, some science educators felt that "it is unrealistic to expect a blind student to be a chemist" (Norman et al., 1998, p. 137). Contrary to these educators' beliefs, "there are in fact many blind chemists" (Norman et al., 1998, p. 137)-which indicates that our society has serious misconceptions about the abilities of individuals with disabilities. Such negative societal views about individuals with disabilities have been influenced by the medical model of disability that has medicalised disabilities and illness such that individuals with disabilities have been portrayed as problematic by society. Simon Brisenden (1986), a philosopher and poet with a disability, explained that the medical model is to blame for portraying people with disabilities as weak, pathetic, and in need of constant sympathy from "normal" individuals. This model has presented individuals with disabilities as physically and intellectually dysfunctional and in need of constant medical supervision (Brisenden, 1986).

Individuals with disabilities, and some researchers, have argued that the medical model puts its entire emphasis on "within-child factors, stressing the impairment and underplaying, even ignoring, the environmental factors" (Lindsay, 2003, p. 5). Many individuals with disabilities believe that it is equally important to consider contextual issues within society. Specifically, learning disabilities might be due to "the result of situations rather than attributes of individuals across situations" (Roth \& Barton, 2004, p. 133). For example, the academic performance of students with LD might be affected by contextual factors (e.g., teaching strategy) rather than cognitive deficits, as shown in a study conducted by Roth and Barton (2004).

Roth and Barton (2004) explored how an authentic science activity related to a real-life problem (e.g., pollution impacts on a creek) affected science learning. These researchers observed that one of the participants (Davie), a 13-year-old student, had severe writing problems and ADHD and was performing below average in math and science in regular classroom. However, with the authentic science learning approach, Davie emerged as a highly literate science student instead of a science failure diagnosed with LD. In addition, Davie was helping his peer, typically achieving, students with the inquiry-based activities at the creek. It is clear that Davie's difficulty in learning science was not due to his disability, as was portrayed by the medical model of disability. Instead, Davie's problem was located in the science teaching approach employed by his teacher.

Such views resonate with the social model of disability, which postulates that LD is socially constructed and "caused by the inflexibility of the school system and by its inability to meet the diversity of children" (Terzi, 2005, p. 447). Below, I describe and discuss the social model of disability, explain how 
the social model guided my teaching practice, and discuss the limitations of the social model of disability as a reserch lens.

\section{Understanding Disability from the Insider's Perspective: The Social Model of Disability}

It wasn't my body that was responsible for all my difficulties, it was external factors, the barriers constructed by the society in which I live. I was being dis-abled-my capabilities and opportunities were being restricted-by prejudice, discrimination, inaccessible environments, and inadequate support. (Crow, 1996, p. 2)

In June 2013, I came across an article by Liz Crow, who advocates for disability rights through her films and public performances. Her article, which resonates with the social model of disability, offered me the opportunity to make sense of how individuals with disabilities define and experience their disabilities.

Originating in the 1960s, the social model of disability explains that individual limitations or deficits as postulated by the medical model of disability are not the real problem; the core issue dwells in society's failure to address the needs of people with disabilities in its social structure (Oliver, 2009). As emphasised by Oliver (2009), "the social model of disability insists that disablement has nothing to do with the body. It is a consequence of social oppression" (p. 23). This model embraces the philosophy that changes are required in society's practices to remove the barriers that discriminate against individuals with disabilities (Oliver, 2009). Specifically, by providing an inclusive and supportive environment, free of prejudice and discrimination, individuals with disabilities are offered opportunities to fully participate in society (Oliver, 2009; Terzi, 2005). By embarking on a journey of empowerment and resilience, embodied within the social model of disability, individuals with disabilities began to redefine disability research and practice through their collective voices via artbased performances, films, and writing.

Brisenden (1986) explained that "to understand disability as an experience, as a living thing, we need more than medical facts. ... Our experiences must be expressed in our words and integrated in the consciousness of mainstream society" (p. 173-174). As a researcher-practitioner attempting to improve science education for students with LD, I feel inspired by the words of Brisenden (1986) and those individuals with disabilities advocating for disability rights. I feel that voices of individuals with disabilities need to be valued and researched because they are strong, powerful, independent, and insightful individuals who construct and contribute meaningfully to society.

Based on my practical experience as a special needs educator, I am convinced that the views shared by individuals with disabilities are crucial to constructing a more equitable and fair society, and will lead to changes for their well-being and society's as a whole. In the following vignette, I discuss the importance of paying close attention to the voices of science students with LD to design strategies that best support and empower them.

\section{Vignette II: Listening to the voices of students with LD.}

I am very concerned about Wise's progress in learning biology. Wise was diagnosed with dyslexia and processing deficits. I have employed all the research-based learning strategies (e.g., graphic organisers, mnemonics, cue cards) that focus on improving academic performance of science students with LD but to no avail. 
Today was Week 7 of the remedial tutoring sessions that I conducted with Wise to support her learning. I decided to use another approach. I asked her about her interests and she told me that she loves pictures and is passionate about drawing and doodling.

Thinking on my feet, I downloaded a couple of black and white pictures on mitosis. I magnified the pictures using the paint application so that the organelles and different stages in mitosis would be more apparent. She seemed mesmerised by the size of the pictures.

At that moment, I knew that I had managed to capture her attention. She was very engaged during the tutorials and commented on the shape and positioning of the organelles. She even took out her coloured pencils and coloured the organelles. By the end of the session, she had grasped a good chunk of the material. Before she left, she said: "I cannot believe it's over, I didn't see the time go by. I was having so much fun with you. And I think I understand bio now." (Personal notes, special needs educator report log, fall semester, 2013)

Through my work with Wise, and the hundreds of students whom I have worked with throughout my career as a special needs educator, I have come to realise that each student is unique in her or his disability, personality, and interests. This should not be surprising because although human beings share similarities, their genetic codes are unique, making them interestingly diverse. Therefore, how can we expect that a single strategy (e.g., the inquiry-based approach) will benefit all students? From my experience, listening to students with LD and drawing on their interests and needs are key components to designing strategies that best address their unique struggles. For example, listening to Wise's voice on her interests, and capitalising on her strengths as an art lover, paved the way for me to implement a learning strategy that not only engaged her but contributed to her success in biology. In turn, Wise felt empowered because she understood the concepts of mitosis. As emphasised by Maestri-Banks and Pope (2011), individuals feel empowered when they are supported in reaching a specific goal.

\section{Informing my Teaching Practice Through the Social Model of Disability}

When I started teaching biology in January 2015, I was determined to create an inclusive learning environment for all my students, one that was not only free of discrimination and prejudice, but also allowed all students-irrespective of their abilities, gender, cultural background, social circumstances, and career aspirations - to fully participate in my class (American Association for the Advancement of Science, 1990). It is crucial for me that my students feel safe to engage in learning instead of feeling segregated and stigmatised (Baurhoo \& Asghar, 2014). Moreover, my teaching approach capitalises on the cognitive, cultural, and social strengths of diverse learners rather than focusing on their cognitive deficits (Baurhoo \& Asghar, 2014).

I adopt a universal design to my teaching approach that embeds multiple ways of representing taught concepts, engaging students during instruction, and assessing students to support their cognitive development (Rose, Harbour, Johnston, Daley, \& Abarbanell, 2006). Instead of only presenting information orally and through PowerPoint lectures, I work towards co-constructing biological knowledge with my students, which involves conducting small experiments in the classrooms, drawing out taught concepts, watching videos on specific biological concepts, interpreting biological figures and diagrams, problem solving with authentic biology-related cases, and learning collaboratively with their peers. For assessments, I provide opportunities for my students to demonstrate their knowledge of taught concepts orally through presentations, drawing concept maps, building models, and taking traditional quizzes and exams. In this way, I tap into the strengths of all my students and offer them multiple and diverse opportunities to learn instead of using a "one size fits all" approach. 
For example, to teach cell biology, I use multiple ways to present the cellular structure and functions. In addition to an interactive lecture that students and I co-construct, students are given opportunities to use art-based materials (e.g., pom-poms, construction paper, playdough) to construct a cell and depict the diverse organelles that regulate the cellular functions (Image 1). The photographs, in Image 1 , bring up vivid memories of my students, who showed unprecedented excitement when they realised that they could buld models.

In every class, I could see the enjoyment and eagerness on my students' faces when I brought out the art supplies so that they could bring biology to life. This idea stemmed from my experience with students like Wise, who taught me that students with LD can be successful learners if their interests and passions are embedded within the teaching and learning strategies. My students also participated in constructing concept maps and completing summary sheets about cellular functions and structure. Not only did these diverse strategies provide alternative representations of the cellular structure and function, they offered multiple ways to engage and assess students. While some students shared with me that the concept maps best helped them learn biology, others explained that they understood the concepts better by constructing biological models using art materials. What matters most to me is that I successfully listen to the unique voices of my diverse students so that I can effectively meet their unique needs.

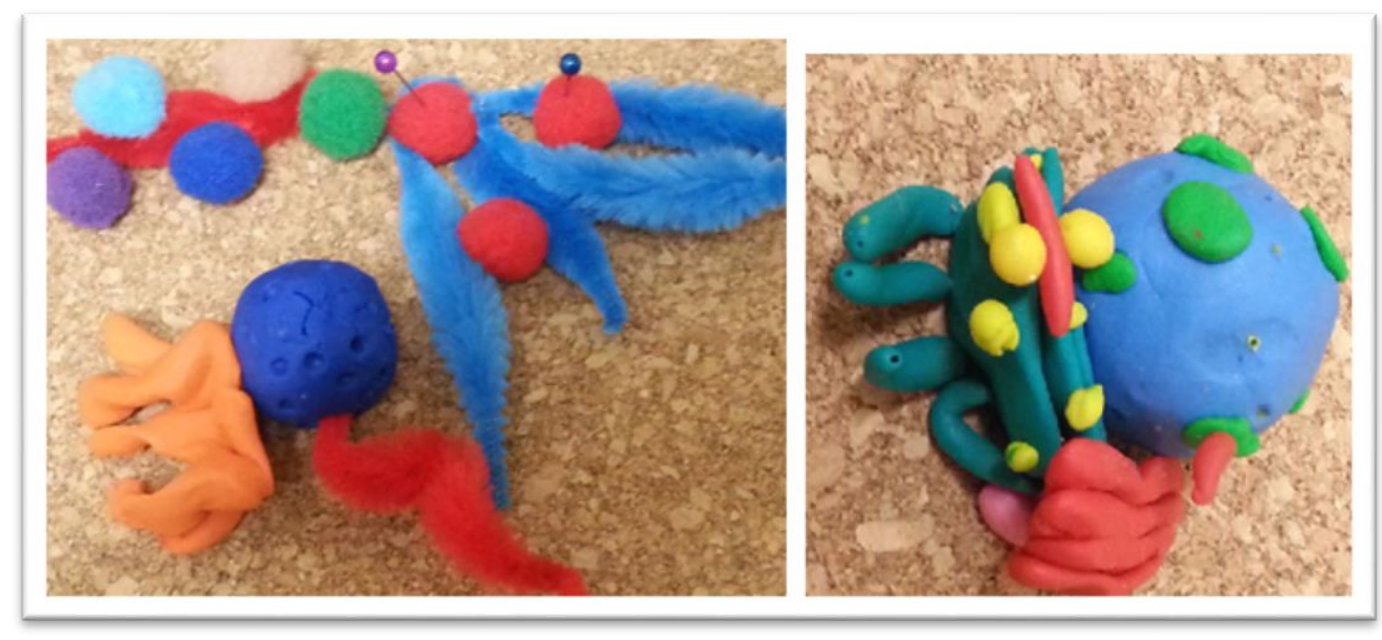

Image 1: Two different models of the cell I co-constructed with my students in a biology class.

\section{Limitations of the Social Model of Disability}

After a few semesters, I noticed that some of my students with special needs (LD, anxiety, and depression) were still struggling in learning biological concepts. In spite of drawing on the social model of disability to favour an inclusive learning environment, some of my students with special needs were barely passing. With much disappointment and despair, my reflections led me to believe that drawing on this model to inform my teaching practice is insufficient to provide a fair and equitable education to my biology students with LD.

Various researchers and disability activists have also argued that the social model of disability is incomplete because it denies impairment (Anastasiou \& Kauffman, 2013; Crow, 1996; Oliver, 2009). Impairment, as defined by the Disabled People's International, "is the functional limitation within the individual caused by physical, mental, or sensory impairment" (as cited in Oliver, 1998, p. 1447). In denying impairment, the social model of disability is "failing to acknowledge the subjective reality of 
many disabled people's daily lives" (Crow, 1996, p. 12). Specifically, by underpinning disability within a sociological lens, the social model of disability neglects to take into account the within-individual attributes of the individual. The social model denies the biological selves of individuals with disabilities and claims that they do not form part of the disability (Anastasiou \& Kauffman, 2013). Consequently, from a social model lens, the person with disabilities is viewed as an incomplete individual, who is "biologically naked and only subjected to social values and roles" (Anastasiou \& Kauffman, 2013, p. 445).

Because these cognitive impairments form part of students' life and experiences, they need to be valued, understood, and addressed along with social issues. By denying these cognitive impairments, the social model of disability does not provide opportunities for individuals to fully express themselves. Sometimes, difficulties experienced by students with LD cannot be addressed solely by altering the environmental or social structure. For example, I have multiple students who experience anxiety in addition to their LD, and they need support from a medical expert to deal with anxiety. In some cases, to succeed academically, they might need medication in addition to an inclusive environment suited to meet their needs.

Based on my professional experience and the current disability discourses, I recognise that students with LD are whole individuals with intricate biological, psychological, and social attributes. As a doctoral student exploring academic barriers faced by science students with LD, I have come to understand that it is imperative to give them the opportunities not only to discuss the social barriers that affect them, but also the biological and psychological problems that they encounter.

\section{Bronfenbrenner's Ecological Model: Transforming Science Education and Research for All}

I have explored the possibility of employing a disability lens that takes into account the complexity of barriers-encompassing the biological, psychological, and social factors-that students with disabilities encounter in learning science. After a thorough search of the literature, I found my voice in Bronfenbrenner's $(1979,1986,1994,2005)$ ecological model as a framework that informs both my practice and my doctoral research study. Bronfenbrenner (2005) posited that individuals' development processes (e.g., biological, psychological, social, emotional, and cognitive) are shaped by the intricate, bidirectional interactions between their within-individual attributes (e.g., self-confidence, resilience, motivation) and the multilayered environment in which individuals develop. I strongly believe that Bronfenbrenner's ecological model offers a meaningful lens to develop an in-depth and comprehensive understanding of the barriers impacting the lives of individuals with disabilities.

Unlike the medical model of disability, which narrowly defines within-individual characteristics on the basis of impairment, Bronfenbrenner's (2005) ecological model offers a more holistic view of withinindividual attributes. Specifically, this model invites us to view individual characteristics not only from an impairment perspective as emphasised by the medical model of disability, but also from a position of power. For example, while focusing on within-individual characteristics of students with LD, Bronfenbrenner's ecological model permits us to make sense of their positive qualities such as resilience and determination to succeed. Simultaneously, Bronfenbrenner's ecological model invites us to construct a deeper understanding of diverse ecological barriers located within a complex and multidimensional ecological system as opposed to the social model of disability, which outlines few barriers (e.g., environmental, social, and attitudinal). 


\section{Towards Transforming Science Teaching and Learning for Students with LD: An Ecological Perspective}

As a college biology teacher aiming to provide a just and inclusive science education for all my students, I have found that Bronfenbrenner's (2005) ecological model provides an exciting and innovative lens through which I can make sense of my students' learning problems as stemming from different structures (classroom, home, family, and others). As illustrated in the vignette below, I drew on Bronfenbrenner's ecological model to develop a comprehensive understanding of the diverse issues impacting students' with LD academic achievement and success in my biology classroom.

\section{Vignette III: Where is the barrier: In the individual, the environment, or both?}

Amber, a student with $L D$, had been failing most of the quizzes and tests in my class. Yet, Amber had a strong determination to succeed. She came to see me often to go over quizzes and tests.

To support Amber in successfully learning biology, I suggested that she take free remedial tutoring with me. But, first, it was crucial for me to identify the potential set of barriers affecting her learning process. Drawing on Bronfenbrenner's (2005) ecological model, I built a schema to map all the possible barriers that could impact Amber's learning. To fulfil this task, I kept an open mind and asked many questions: What barriers are impeding Amber's learning process? Is it the classroom? My teaching style? Disability-related? Within Amber's home environment? I spoke with her to figure out the exact types of barriers that have impeded her academic success in biology.

To further understand these barriers, I carefully observed her during the tutorial sessions. I noticed her difficulties in remembering biological terminology and vocabulary. When we discussed the PowerPoint presentations from previous classes, she would not recall that we had gone over these concepts in class. I also observed that Amber learnt by verbally reciting the slides. She explained to me that she did not feel comfortable writing notes and shared that the learning specialist at the college supported her strategy of learning verbally.

Still, I suggested that she write notes, as it might help her understand and recall the concepts. During our remedial tutorials, I integrated a notetaking strategy amongst other strategies (drawing, building models). We would first discuss biological concepts by drawing and building models. Then, she would orally explain to me the concepts in her own words or by drawing or using models. As she explained the concepts, I would write out short notes for her. Each session, I suggested that she write the notes, but she always declined. After a month, she started writing her own notes (see Image 2). At the end of the semester, Amber's comprehension of biology improved sufficiently. She passed the biology course with a $61 \%$. However, she still performed at a much lower academic level than the class average (73\%). (Personal teacher diary, fall semester, 2015) 


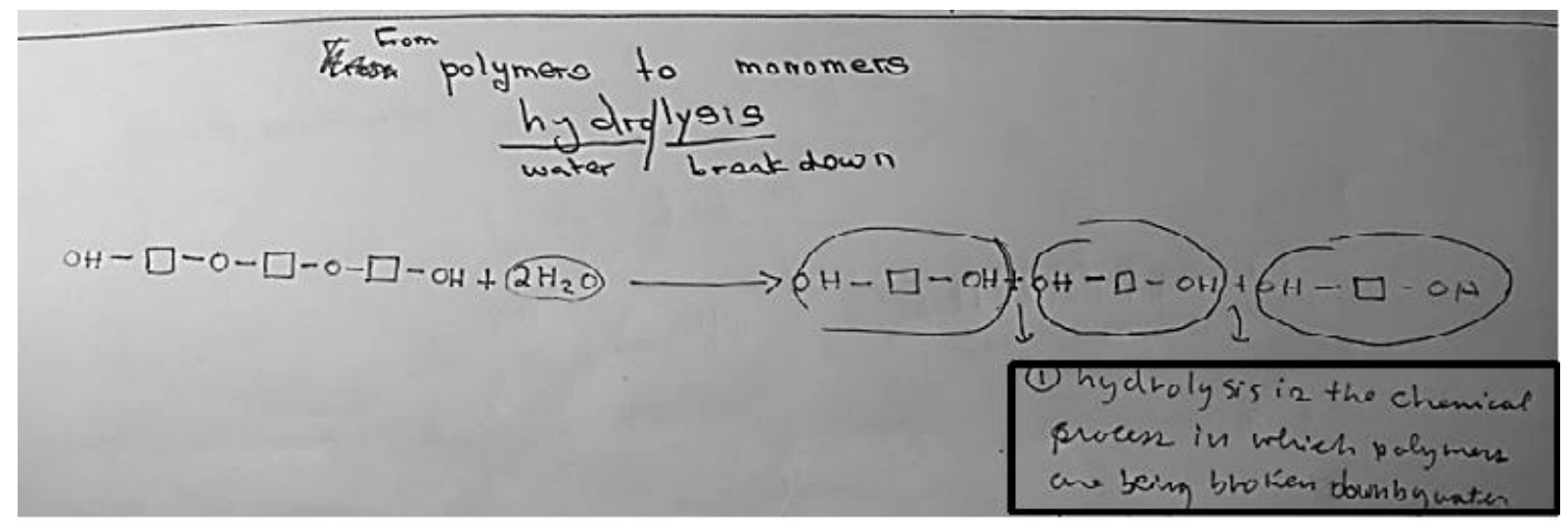

Image 2: The handwriting in the black box represents Amber's first attempt in writing biology notes.

Drawing on Bronfenbrenner's (2005) ecological model, I positioned Amber at the heart of the ecological system (see Figure 1 below). I recognised that Amber's learning process in biology was being shaped by a myriad of complex interactions that took place between (a) her personal characteristics (encompassing her biological, psychological, social, emotional attributes) and (b) her environment (classroom, college, home). According to Bronfenbrenner (2005), the environment is complex and webbed in a set of four nested subsystems-microsystem, mesosystem, exosystem, and macrosystem. As illustrated in the vignette, to support Amber's learning, it was crucial that I identify the potential barriers that were hindering her learning process within her ecological system. I attempted to map the potential barriers experienced by Amber within the four subsystems. ${ }^{5}$

\footnotetext{
${ }^{5}$ The macrosystem, which embeds societal and cultural beliefs regarding disabilities, was not considered as a barrier within Amber's college. On the contrary, the college policies guide best practices for individuals with disabilities.
} 
Figure 1: Amber's ecological system: Within-individual and contextual factors impacting learning.

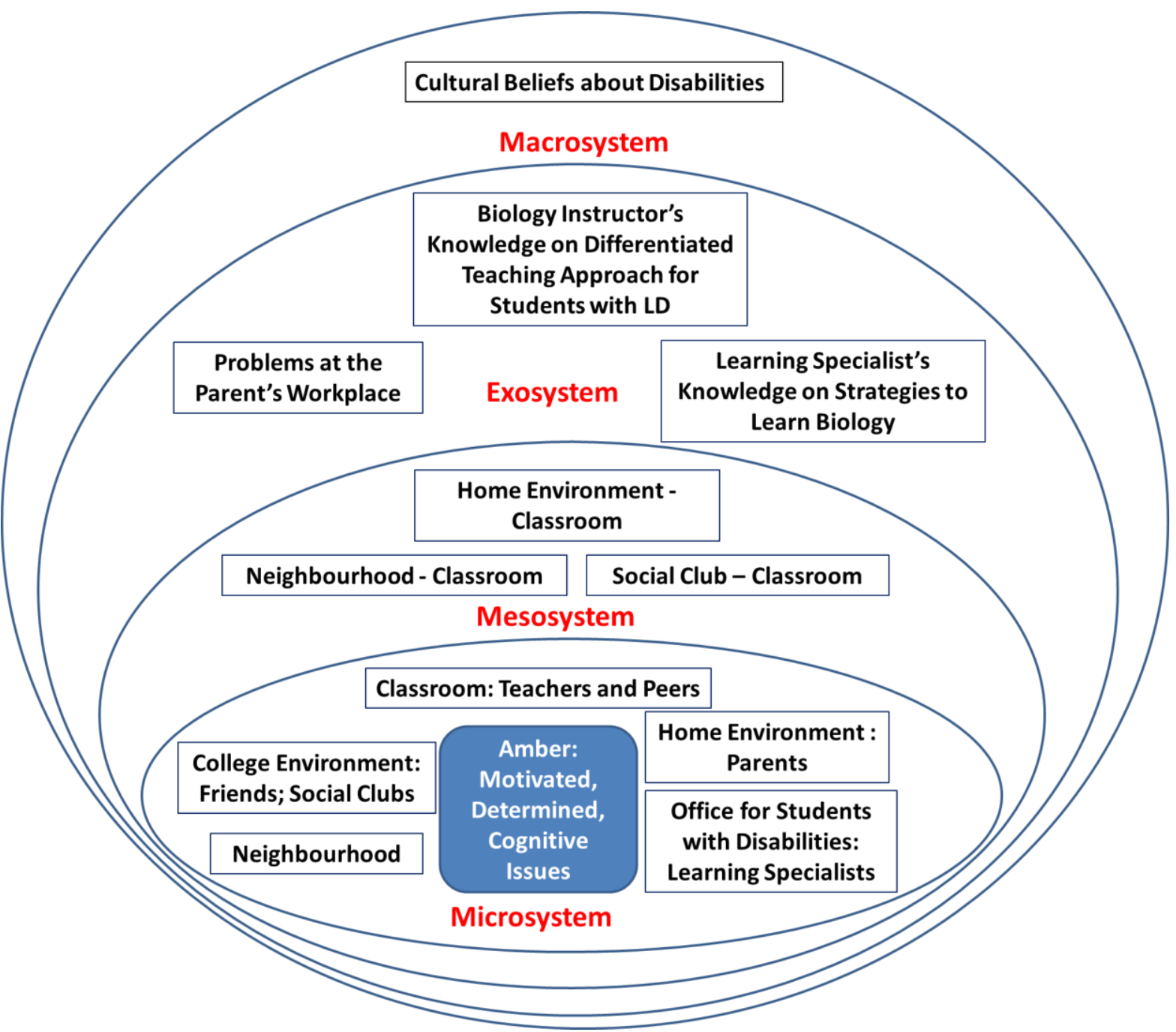

The microsystem represents the immediate environment in which Amber is physically present and directly interacts with others-teachers, peers, and parents-(Bronfenbrenner, 2005). Amber continuously interacts and builds relationship with others (me as her biology instructor, parents, friends, etc.). These direct relationships (e.g., individual-peer relationship) might positively or negatively impact her learning process. For example, it is well documented that students with LD are not always accepted by their peers, who make them feel devalued, and withdraw from peer-to-peer interactions (Cambra \& Silvestre, 2003). In my biology classroom, peer-assisted learning is central to my practice. Therefore, if the relationship between Amber and her typically achieving peers is unfavourable during peer-related activities, it is likely that her academic performance would be affected.

In the same vein, I analysed potential barriers impeding Amber's learning within the mesosystem. The mesosystem is defined by the linkages and processes taking place between two or more microsystems in which the individual is physically active (Bronfenbrenner, 2005). In particular, interactions in one microsystem (e.g., an individual's home) might influence behaviour in another microsystem - such as an individual's school-(Eamon, 2002). I identified a few connections between different microsystems that might negatively affect Amber's learning process in biology (see Figure 1). For example, Amber 
might lack support from her parents (one microsystem), which could negatively impact Amber's learning process in the biology classroom (another microsystem). In line with my views, various empirical studies have demonstrated that high school and post-secondary students with supportive parents perform better academically as compared to those with unsupportive parents (Gonzales, Cauce, Friedman, \& Mason, 1996; Gutman, Sameroff, \& Eccles, 2002).

The exosystem is defined as:

the linkages and processes taking place between two or more settings, at least one of which does not contain the developing person, but in which events occur that indirectly influence processes within the immediate setting in which the developing person lives. (Bronfenbrenner, 1994, p. 40)

Bronfenbrenner (2005) posited that exosystems, such as parents' workplace and a teacher's personal life and experiences, do not directly involve the developing individual, but can indirectly impact the development of a school-aged child. Bronfenbrenner (2005) exemplified the exosystem by discussing that mothers who were forced to quit their jobs and take care of their babies were found to more likely mistreat their progenies. In this example, the changes that previously took place in the mothers' professional lives constituted an exosystemic barrier affecting the well-being of their developing children.

Similarly, while working with Amber, I drew on my own life experiences to support Amber's learning process in biology. For example, to explore and implement effective instructional strategies that could contribute to Amber's success in biology, I drew on my prior knowledge gained from previously taking courses in special needs education at the university. However, the knowledge that I constructed in the university setting was not particularly conducive in helping Amber to succeed in my course. Moreover, I also sought advice from my most experienced colleagues to gain new insights on ways to best support Amber's learning. My prior knowledge obtained from the university setting on differentiated teaching strategies for science students with LD, and subsequent interactions with my colleagues, englobed a unique professional exosystemic setting that "does not contain the developing person," namely, Amber (Bronfenbrenner, 1994, p. 40). Yet, my prior experiences and events that occurred in my professional sphere "indirectly influence processes within the immediate setting in which the developing person lives" (Bronfenbrenner, 1994, p. 40). Specifically, before the beginning of the individualised tutorials with Amber, my inadequate knowledge of effective strategies to meet Amber's unique learning style within the classroom setting constituted an exosystemic barrier that affected Amber's academic performance in biology. Moreover, the strategies (e.g., using a universal design for teaching approach) that my colleagues suggested to me were already implemented in my classroom and did not contribute to favour Amber's scholarship in biology.

Initially I focused on the potential barriers impacting Amber's learning and had yet to understand the realistic issues that Amber was experiencing. I engaged Amber in a discussion on the potential problems that I identified above and depicted in Figure 1. From these conversations, it seemed that she was experiencing two major issues in learning biology. First, her learning strategy (located at a within-individual level) was negatively impacting her learning. Second, Amber was also facing barriers from the exosystemic level, which constituted the learning specialist. During my meeting with the learning specialist, she confessed that she was trained in psychology at the university setting, but she had no background in science education and was unaware of strategies to support students with LD in science. In turn, her experiences and knowledge gained from the university setting, in which Amber was physically absent, "indirectly influence processes within the immediate setting in which the developing person lives" (Bronfenbrenner, 1994, p. 40) such that her lack of familiarity in science 
teaching and learning for students with LD was partly affecting Amber's ability to adopt effective studying strategies to favour her understanding of biology. Moreover, she explained that she was merely reinforcing Amber's choice to not write class notes as a means to motivate her and improve her self-confidence. As explained in the vignette, by offering Amber one-on-one tutorials and focusing on her academic needs, I was able to support her effectively by employing multiple strategies.

By employing Bronfenbrenner's ecological model as a practical lens, I was able to depict a holistic, but accurate and clear picture of different aspects of Amber's life as a student. When I showed the diagram in Figure 1 to Amber, she smiled and engaged in an animated conversation with me regarding her supportive friends, dedicated parents, and the nutrition club at the college. Her face lit up when she saw that I described her as motivated and determined. She kept thanking me for recognising that she has potential. Unbeknownst to me at that time, my relationship with Amber would grow and flourish. She seemed to trust me and attempted strategies that I proposed. In my experience, Bronfenbrenner's ecological model is a unifying framework that brings into play positive ways to favour students' learning and self-worth.

\section{Towards Transforming Disability Research in Science Education: The Ecological Model of Disability}

As previously discussed, Bronfenbrenner's ecological model was revolutionary in transforming my teaching practice to comprehend barriers experienced by students with LD, and meet their particular academic needs. While working closely with students with LD, it became even more evident that the issues they experienced encompassed a multitude of within-individual and contextual factors, which are embedded within a multilayered web of complexity. As evident in Amber's case, Bronfenbrenner's ecological model permitted me to map all the possible barriers that a student with LD might experience in a learning situation. With this in mind, I drew on Bronfenbrenner's ecological model as a lens to inform my doctoral study, and I was able to capture voices of students with LD and unveil the complex, interwoven barriers that impede their learning processes in science.

Unfortunately, to my knowledge, no study has drawn on the ecological model to discuss withinindividual and contextual barriers impacting students' with LD learning and academic achievement in science education. By drawing on the ecological model, I made sense of within-individual issues, contextual issues, and the intersection of within-individual and contextual issues affecting students' pursuit of scholarship in science. Moreover, the ecological model has allowed me to move away from traditional approaches used in research inquiries that explore a limited range of factors located at the within-individual or contextual levels instead of attempting to explore barriers across ecological systems (Bronfenbrenner, 2005).

As I near the end of my doctoral journey, I feel that I am no longer enslaved by the medical model of disability, which compelled me to construct my understanding of disability from a cognitive deficit perspective. Nor am I entirely positioned within the social model of disability, which prevented me from making sense of students' issues from a cognitive deficit perspective. Bronfenbrenner's (2005) ecological lens has inspired me to construct my understanding of issues from a holistic perspective, allowing me to make sense of Amber's and other students' academic problems from multiple systems, transform my teaching practice, and contribute effectively to the academic success of my students with LD.

\section{Conclusion}


In this autoethnographic inquiry, I unveiled the delicate process of attempting to position myself within a disability discourse to inform my doctoral research study, with the objective of transforming and improving science education for students with LD. I found myself at the heart of constant stress and tension as I navigated opposing discourses: the medical and social models of disability. Drawing from my dual identities as a practitioner-researcher, I engaged in a reflexive process on the potential application of the social and medical models in informing barriers experienced by students with LD.

My journey was laden with countless difficulties because I was tempted to employ the powerful and highly revered medical model of disability. On the other hand, I was also tempted to employ the social model of disability because it is gaining popularity in the disability research literature. Yet, in this autoethnographic inquiry, I have come to challenge both the medical and the social models of disability as inadequate and incomplete in informing a deep and comprehensive understanding of issues experienced by students with LD. Moreover, these frameworks are not in line with my objectives of transforming and improving science education through the identification of authentic barriers impacting students with LD learning.

After struggling to position myself within a discourse that could inform my doctoral research study, the ecological model became my voice. My experiences as a practitioner were the determining factor in deciding to draw on the ecological model to inform my doctoral thesis. As evident in my practice and research with students like Amber, the ecological model provides a more holistic, in-depth understanding of both within-individual and contextual barriers that students with LD face in their daily struggles in science learning. During my doctoral work, the ecological lens permitted me to listen to the unheard and silenced voices of students with LD.

While no two doctoral journeys are alike, I am certain that other doctoral students embodied within the practitioner-researcher identities might also be experiencing dilemmas in framing their doctoral study and positioning themselves within a specific discourse. I argue that an autoethnographic inquiry such as this can empower other doctoral students and researchers to find their voices within discourses that favour social change and improve academic lives of minority students, while taking a stance against traditional, powerful, and popular discourses.

\section{References}

Alloway, T. P. (2009). Working memory, but not IQ, predicts subsequent learning in children with learning difficulties. European Journal of Psychological Assessment, 25, 92-98. http://doi:10.1027/1015-5759.25.2.92

American Association for the Advancement of Science. (1990). Project 2061: Science for all Americans. New York, USA: Oxford University Press.

Anastasiou, D., \& Kauffman, J. M. (2013). The social model of disability: Dichotomy between impairment and disability. Journal of Medicine and Philosophy, 38(4), 441-459. http://doi:10.1093/imp/iht026

Anderson, L. (2006). Analytic autoethnography. Journal of Contemporary Ethnography, 35(4), 373395.

Baurhoo, N., \& Asghar, A. (2014). Using universal design for learning to construct inclusive science classrooms for diverse learners. Inclusive Education: Socially Just Perspectives and Practices, 7, 5981. 
Brigham, F. J., Scruggs, T. E., \& Mastropieri, M. A. (2011). Science and students with learning disabilities. Learning Disabilities Research and Practice, 26, 223-232. http://doi:10.1111/i.15405826.2011.00343.x

Brisenden, S. (1986). Independent living and the medical model of disability. Disability, Handicap \& Society, 1(2), 173-178. http://doi:10.1080/02674648666780171

Bronfenbrenner, U. (1979). The ecology of human development. Cambridge, USA: Harvard University Press.

Bronfenbrenner, U. (1986). Ecology of the family as a context for human development: Research perspectives. Developmental Psychology, 22, 723-742. http://doi:10.1037/0012-1649.22.6.723

Bronfenbrenner, U. (1994). Ecological models of human development. In International Encyclopedia of Education (Vol. 3, 2nd ed., pp. 1643-1647). Oxford, UK: Elsevier Sciences.

Bronfenbrenner, U. (2005). Making human beings human: Bioecological perspectives on human development. Thousand Oaks, USA: SAGE.

Cambra, C., \& Silvestre, N. (2003). Students with special educational needs in the inclusive classroom: Social integration and self-concept. European Journal of Special Needs Education, 18(2), 197-208. http://doi:10.1080/0885625032000078989

Crow, L. (1996). Including all our lives: Renewing the social model of disability. In J. Morris (Ed.), Encounters with strangers: Feminism and disability (pp. 206-226). London, UK: The Women's Press.

Crow, L. (2009, November 24). 13 questions: Liz Crow. Ouch, It's a Disability Thing. Retrieved from http://www.bbc.co.uk/ouch/interviews/13 questions liz crow.shtml

Cruickshank, W. (1971). The brain injured child in home, school and community. London, UK: Pitman.

Daneshamooz, S., Alamolhodaei, H., \& Darvishian, S. (2012). Experimental research about effect of mathematics anxiety, working memory capacity on students' mathematical performance with three different types of learning methods. ARPN Journal of Science and Technology, 2(4), 313-321.

Eamon, M. K. (2002). Effects of poverty on mathematics and reading achievement of young adolescents. The Journal of Early Adolescence, 22(1), 49-74. http://doi:10.1177/0272431602022001003

Ellis, C. (1999). Heartful autoethnography. Qualitative health research, 9(5), 669-683.

Ellis, C. (2004). The ethnographic I: A methodological novel about autoethnography. Walnut Creek, USA: AltaMira Press.

Gonzales, N. A., Cauce, A. M., Friedman, R. J., \& Mason, C. A. (1996). Family, peer, and neighborhood influences on academic achievement among African-American adolescents: One-year prospective effects. American Journal of Community Psychology, 24(3), 365-387. http://doi:10.1007/BF02512027

Gutman, L. M., Sameroff, A. J., \& Eccles, J. S. (2002). The academic achievement of African American students during early adolescence: An examination of multiple risk, promotive, and protective factors. American Journal of Community Psychology, 30(3), 367-399. http://doi:10.1023/A:1015389103911

Hemelsoet, E. (2014). Positioning the educational researcher through reflections on an autoethnographical account: On the edge of scientific research, political action and personal engagement. Ethics and Education, 9(2), 220-233. http://doi:10.1080/17449642.2014.925033

Humphreys, M. (2005). Getting personal: Reflexivity and autoethnographic vignettes. Qualitative Inquiry, 11(6), 840-860. 
Knight, S. A., \& Cross, D. (2012). Using contextual constructs model to frame doctoral research methodology. International Journal of Doctoral Studies, 7, 39-72. Retrieved from http://ijds.org/Volume7/IJDSv7p039-062Knight234.pdf

Kozey, M., \& Siegel, L. S. (2008). Definitions of learning disabilities in Canadian provinces and territories. Canadian Psychology, 49(2), 162-171. http://doi:10.1037/0708-5591.49.2.162

Larochette, A-M., \& Harrison, G. A. (2012). Word memory test performance in Canadian adolescents with learning disabilities: A preliminary study. Applied Neuropsychology: Child, 1, 38-47. doi:10.1080/21622965.2012.665777

Learning Disabilities Association of Canada (LDAC). (2015). Official definition of learning disabilities. Ottawa, Canada: LDAC. Retrieved from http://www.ldac-acta.ca/learn-more/ld-defined/officialdefinition-of-learning-disabilities

Lindsay, G. (2003). Inclusive education: A critical perspective. British Journal of Special Education, 30, 3-12.

Lyons, R., \& Roulstone, S. (2016). Labels, identity and narratives in children with primary speech and language impairments. International Journal of Speech-Language Pathology, 1-16. doi: $\underline{10.1080 / 17549507.2016 .1221455}$

Maestri-Banks, A., \& Pope, P. (2011). Professional and interpersonal skills. In P. Birchenall \& N. Adams (Eds.), The nursing companion. Basingstoke, UK: Palgrave Macmillan.

Mastropieri, M. A., Scruggs, T. E., Boon, R., \& Carter, K. B. (2001). Correlates of inquiry learning in science: Constructing concepts of density and buoyancy. Remedial and Special Education, 22, 130138.

Norman, K., Caseau, D., \& Stefanich, G. P. (1998). Teaching students with disabilities in inclusive science classrooms: Survey results. Science Education, 82(2), 127-146. http://doi:10.1002/(SICI)1098237X(199804)82:2<127::AID-SCE1>3.0.CO;2-G

Oliver, M. (1998). Theories in health care and research: Theories of disability in health practice and research. British Medical Journal, 317(7170), 1446-1449.

Oliver, M. (2009). The social model in context. In R. Michalko \& T. Titchkosky (Eds.), Rethinking normalcy: A disability studies reader (pp. 19 - 30). Toronto, Canada: Canadian Scholars' Press.

Rose, D. H., Harbour, W. S., Johnston, S. C., Daley, S. G., \& Abarbanell, L. (2006). Universal design for learning in postsecondary education: Reflections on principles and their applications. Journal of Postsecondary Education and Disability, 19, 135-151.

Roth, W.-M., \& Barton, A. C. (2004). Rethinking scientific literacy. New York, USA: Routledge.

Scruggs, T. E., \& Mastropieri, M. A. (1994). The construction of scientific knowledge by students with mild disabilities. The Journal of Special Education, 28, 307-321. http://doi:10.1177/002246699402800306

Stanley, P. (2014). Writing the PhD journey(s): An autoethnography of zine-writing, angst, embodiment, and backpacker travels. Journal of Contemporary Ethnography, 44(2), 143-168.

Terzi, L. (2005). Beyond the dilemma of difference: the capability approach to disability and special educational needs. Journal of Philosophy of Education, 39, 443-459.

Weaver-Hightower, M. B. (2012). Waltzing Matilda an autoethnography of a father's stillbirth. Journal of Contemporary Ethnography, 41(4), 462-491. 